\title{
MIH - epidemiological study on a sample from Paedodontics Department
}

\author{
MIH - studiu epidemiologic pe un lot de copii dintr-o clinică de pedodonţie
}

\author{
Mihaela Tănase, Ioana-Andreea Stanciu, Aneta Munteanu, Daciana Zmărăndache, \\ Cătălina Farcaşiu, Rodica Luca \\ Disciplina Pedodonţie, Facultatea de Medicină Dentară, UMF „Carol Davila“, Bucureşti, România
}

\begin{abstract}
Objectives. To assess the distribution, topography and severity of $\mathrm{MIH}$ lesions as well as the associated carious in a group of children examined at the Pedodontics Department, Bucharest.

Material and method. Retrospective descriptive observational study performed on dental records of 100 patients (38 boys) (6-12 years) diagnosed with $\mathrm{MIH}$. The distribution, topography and severity of MIH defects, as well as associated decay were recorded. There were calculated: the number of patients with $\mathrm{MIH} /$ $\mathrm{MH}$, the average number of first permanent molars (M1p)/permanent incisors (I) with $\mathrm{MIH} /$ patient, the distribution of M1p/l affected according to the topography and severity of the defects, the mean number of $\mathrm{M} 1 \mathrm{p}$ with $\mathrm{MIH}$ and associated caries/patient. Statistical analysis was performed with SPSS 18.0 using ANOVA and t-test $(p<0.05)$.

Results. Patients with $\mathrm{MIH}=52 \%$, patients with $\mathrm{MH}=48 \%$. Girls $(62 \%)$ were statistically significantly more affected than boys $(38 \%)(p<0.05)$. Mean number of affected M1p/patient $=3.66$ and mean number of affected $\mathrm{I} /$ patient=1.24. The most interested were $46(95 \%)$ and $11(56.66 \%) .69 .67 \%$ of $\mathrm{M} 1 \mathrm{p}$ with MIH had hypomineralization in occlusal third $(20.21 \%$ at the top of the cusps, $13.66 \%$ at the bottom of the cusps and $35.79 \%$ on all occlusal third) and $7.92 \%$ in the medium third. $26.8 \%$ of M1p with MIH had mild defects, $46.4 \%$ moderate defects, $26.8 \%$ severe defects. The mean $\mathrm{M} 1 \mathrm{p}$ with $\mathrm{MIH}$ and associated decay/patient = 2.7: $52.18 \%$ with uncomplicated caries and $21.31 \%$ with complicated caries.

Conclusions. The severity of MIH in the studied group is high; It is necessary to early diagnose $\mathrm{MIH}$ lesions in order to prevent further complications.
\end{abstract}

Keywords: M1p, MIH defects, caries lesions

\section{REZUMAT}

Obiective. Evaluarea distribuţiei, topografiei şi severităţii leziunilor MIH şi a proceselor carioase asociate acestor defecte la un lot de copii examinaţi la Disciplina de Pedodonţie, Bucureşti.

Material şi metodă. Studiu retrospectiv observaţional descriptiv realizat pe fişele stomatologice a 100 de pacienţi (38 băieţi) (6-12 ani) diagnosticaţi cu MIH. S-au înregistrat distribuţia, topografia şi severitatea defectelor $\mathrm{MIH}$, precum şi leziunile carioase asociate. S-au calculat: numărul pacienţilor cu $\mathrm{MIH} / \mathrm{MH}$, numărul mediu de molari unu permanenti (M1p)/incisivi permanenţi (I) cu MIH/pacient, distribuţia M1p/l afectaţi în funcţie de topografia şi severitatea defectelor, numărul mediu de $\mathrm{M} 1 \mathrm{p}$ cu MIH şi carii asociate/pacient. Prelucrarea statistică s-a realizat cu programul SPSS 18.0, folosind testele ANOVA şi t-test $(p<0,05)$.

Rezultate. Pacienţi cu $\mathrm{MIH}=52 \%$, pacienţi cu MH $48 \%$. Fetele $(62 \%)$ au fost semnificativ statistic mai afectate decât băieţii $(38 \%)(p<0,05)$. Media M1p afectaţi/pacient=3,66 şi media I afectaţi/pacient=1,24. Cei mai interesaţi au fost dinţii 46 (95\%) şi 11 (56,66\%). 69,67\% dintre M1p afectaţi au avut hipomineralizări în 1/3 ocluzală (20,21\% în vârful cuspizilor, $13,66 \%$ la baza cuzpizilor şi 35,79\% pe toată $1 / 3$ ocluzală) şi $7,92 \%$ în 1/3 medie. 26,8\% dintre M1p cu MIH au avut defecte uşoare, 46,4\% defecte medii şi 26,8\% defecte severe. Media M1p cu MIH cu leziuni carioase asociate/pacient a fost 2,7: 52,18\% cu carii simple şi $21,31 \%$ cu carii complicate. Concluzii. Severitatea afectării prin MIH la lotul studiat este mare. Se impune necesitatea depistării precoce a leziunilor MIH pentru a se putea preveni apariţia complicaţiilor.

Cuvinte cheie: M1p, defecte tip MIH, leziuni carioase

\section{INTRODUCERE}

Sindromul MIH (hipomineralizarea molar-incisiv) este definit ca o hipomineralizare sistemică ce afectează unul sau mai mulţi molari primi permanenţi (M1p), asociată sau nu cu hipomineralizarea incisivilor permanenţi $(1,2)$. 
Conform Mathu-Muju şi Wright (2006), leziunile de tip MIH pot fi împărţite în 3 categorii în funcţie de severitate: forma uşoară (opacităţi alb-opace izolate, bine delimitate, mai mari de $1 \mathrm{~mm}$, fără pierderi de smalţ, sensibilitate şi carii asociate), forma moderată (opacităţi galben-maronii bine delimitate, fără luciu post-eruptiv sau prăbuşirea posteruptivă a smalţului/carii limitate la una sau două feţe, fără implicarea cuspidului sau restaurări atipice intacte şi puţin întinse în suprafaţă) şi forma severă (prăbuşirea post-eruptivă extinsă a smalţului sau hipersensibilitate dentară şi/sau carii extinse asociate defectelor smalţului, cu posibilă afectare pulpară sau restaurări atipice foarte extinse corecte sau defectuoase) (3).

Prevalenţa MIH în Europa variază între 3,6 şi 40,2\%, în Asia între 0,48 şi 27,66\%, în America de Sud între 2,54 şi 40,16\% (4), iar severitatea leziunilor diferă de la un dinte la altul, de la un pacient la altul.

Tratamentul este complex din cauza grefării cariilor cu evoluţie rapidă, hipersensibilităţii, dificultăţilor anestezice întâlnite, anxietăţii pacientului şi problemelor de adeziune a materialelor. Alegerea metodei de tratament depinde de vârsta dentară, starea pulpei, pierderea de substanţă dură dentară, stadiul edificării radiculare a molarului doi permanent, prezenţa germenului molarului trei, necesităţile ortodontice, susceptibilitatea la carie şi igiena dentară a pacientului. Astfel, un diagnostic individualizat şi precis va reprezenta cheia către o decizie terapeutică cât mai nuanţată şi adaptată particularităţilor fiecărui caz în parte.
Având în vedere aceste aspecte, prezentul studiu face evaluarea distribuţiei, topografiei şi a severităţii leziunilor de tip MIH, precum şi a leziunilor carioase asociate la un lot de copii examinaţi şi trataţi în cadrul Clinicii de Pedodonţie, Facultatea de Medicină Dentară, UMF „Carol Davila“ din Bucureşti.

\section{MATERIAL ŞI METODĂ}

Lotul a fost format din 100 de pacienţi (38 de băieţi) cu vârsta cuprinsă între 6 şi 12 ani, pacienţi diagnosticaţi cu MIH în Clinica de Pedodonţie din Bucureşti (Fig. 1). Examinarea s-a efectuat pe UNIT-ul dentar, de către un singur examinator. Criteriul de includere a fost prezenţa a cel puţin un M1p cu hipomineralizare pe arcadă, la copii fără afecţiuni generale.

Cercetarea a constat într-o anchetă retrospectivă realizată pe fişsele stomatologice ale celor 100 de copii cu MIH. Din fişe au fost culese date despre vârsta şi sexul pacienţilor, topografia şi severitatea defectelor de tip MIH, leziunile carioase simple sau complicate asociate. Severitatea leziunilor s-a apreciat după Mathu-Muju şi Wright (2006) (3).

Informaţiile au fost introduse într-o bază de date în programul SPSS 18.0. S-au calculat: numărul de pacienţi cu MIH/MH, numărul mediu de M1p/I cu $\mathrm{MIH} /$ pacient, distribuţia M1p şi a incisivilor afectaţi în funcţie de topografia şi severitatea defectelor, numărul mediu de M1p cu MIH şi carii asociate/pacient. Prelucrarea statistică s-a realizat folosind testele ANOVA şi t-test, nivelul de semnificaţie statistică ales fiind $\mathrm{p}<0,05$.

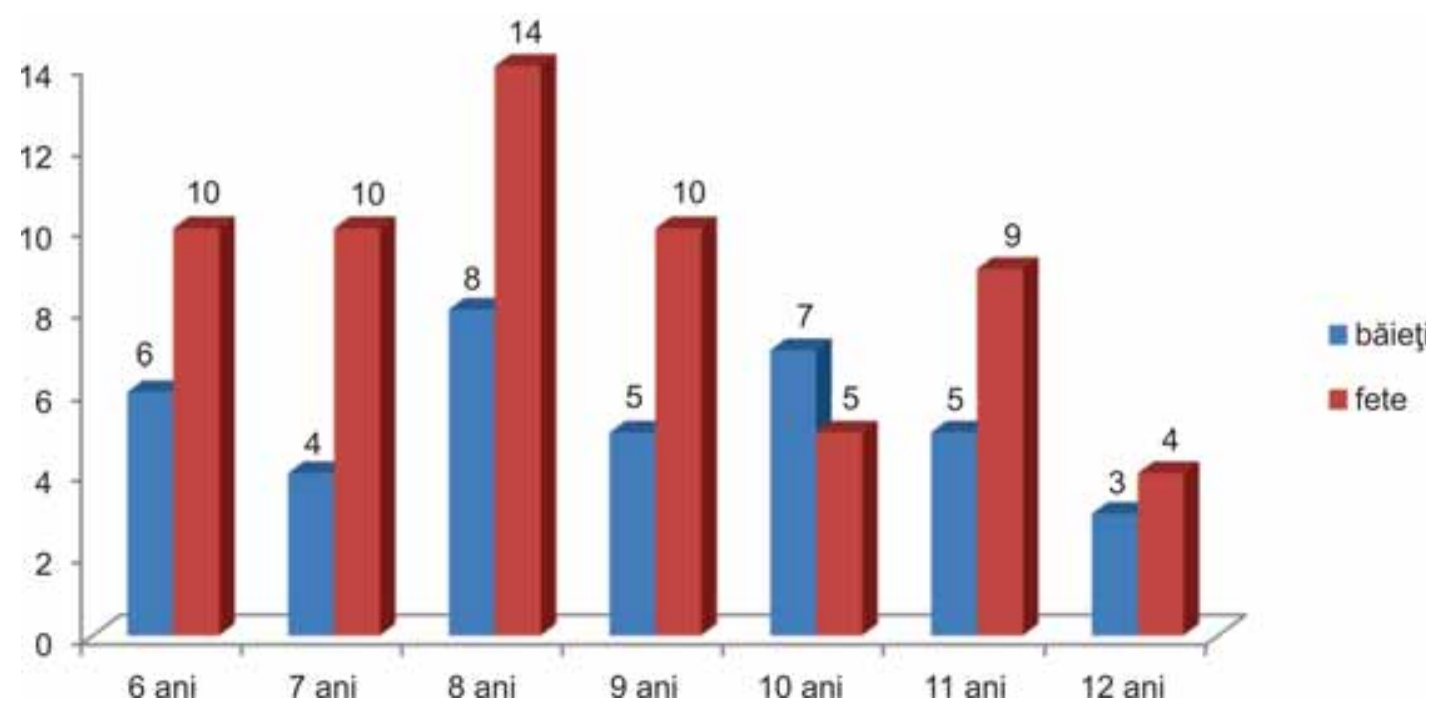

FIGURA 1. Repartiția pe grupe de vârstă şi sex a lotului studiat 


\section{REZULTATE}

\section{a) Distribuția pacienților cu MIH}

S-a constatat că $52 \%$ dintre pacienţi au prezentat hipomineralizări atât pe M1p, precum şi pe incisivi (MIH), în timp ce $48 \%$ au avut hipomineralizari doar pe M1p (MH).

Raportat la sex, s-a constatat că fetele $(62 \%)$ au fost semnificativ statistic mai afectate decât băieţii $(38 \%)(\mathrm{p}<0,05)$.

Media de M1p afectaţi per pacient a fost de 3,66. Majoritatea pacienţilor (80\%) au avut hipomineralizări pe toţi cei patru M1p, 12\% dintre copii - trei molari afectaţi, 3\% dintre copii - doi molari afectaţi şi doar $4 \%$ dintre copii au avut un singur molar afectat.

\section{b) Distribuția M1p cu hipomineralizare}

Din cei 400 M1p prezenţi pe arcadă, 91,5\% $(n=366)$ au prezentat defecte de tip hipomineralizare asociate sau nu cu leziuni carioase, $6,75 \%(n=27)$ au fost indemni atât de carie, cât şi de anomalii de dezvoltare, iar $1,75 \%(n=7)$ au avut doar carii cu tipar obişnuit. M1p cu hipomineralizări au fost clasificaţi în ordinea frecvenţei afectării, toate gradele de severitate fiind luate în considerare. Cel mai interesat dinte a fost 46 (95\%), urmat de 16 şi de 26 (91\%), 36 fiind cel mai puţin afectat $(89 \%)(p>0,05)$.

\section{c) Distribuția incisivilor cu hipomineralizare}

47\% dintre pacienţi au prezentat hipomineralizări pe incisivii maxilari. Procentul de pacienţi cu unul, doi, trei sau patru incisivi maxilari afectaţi a fost de $11 \%, 27 \%, 3 \%$ şi respectiv $6 \%$. 18\% dintre pacienţi au avut $\geq 1$ incisiv mandibular cu hipomineralizare. Procentul pacienţilor cu unul, doi sau trei incisivi mandibulari afectaţi a fost de 11\%,6\% şi, respectiv, $1 \%$.

Raportat la numărul de dinţi, dintre cei 800 de incisivi permanenţi prezenţi pe arcadă, 15,5\% $(124 / 800)$ au prezentat leziuni tip hipomineralizare: $24,5 \%(98 / 400)$ dintre incisivii superiori şi $6,5 \%$ (26/400) dintre cei inferiori. Restul incisivilor au fost indemni. Astfel, arcada maxilară a fost de 3,7 ori mai afectată decât cea mandibulară $(\mathrm{p}<0,05)$. Cei mai afectaţi au fost dinţii 11 şi 21 (56,66\%/ $53,33 \%)$, iar cel mai puţin dintele 31 (11,05\%).

\section{d) Topografia leziunilor MIH}

Cele mai multe defecte de hipomineralizare de la nivelul M1p au fost localizate în $1 / 3$ ocluzală 69,67\% (255/366): 20,21\% (74/366) pe vârful cuspizilor, 13,66\% (50/366) la baza cuspizilor şi $35,79 \%(131 / 366)$ pe toată $1 / 3$ ocluzală. Doar $7,92 \%$ (29/366) dintre leziuni au fost observate în $1 / 3$ medie. Pentru 22,13\% (81/366) dintre M1p cu MIH nu s-a putut preciza topografia din cauza distructiei coronare mari. Distribuţia defectelor MIH la nivelul fiecărui M1p apare în fig. 2.

La nivelul incisivilor, toate leziunile tip $\mathrm{MIH}$ au fost localizate în $1 / 3$ incizală, $34,2 \%$ cu interesarea marginii incizale şi 65,8\% fără interesarea marginii incizale.

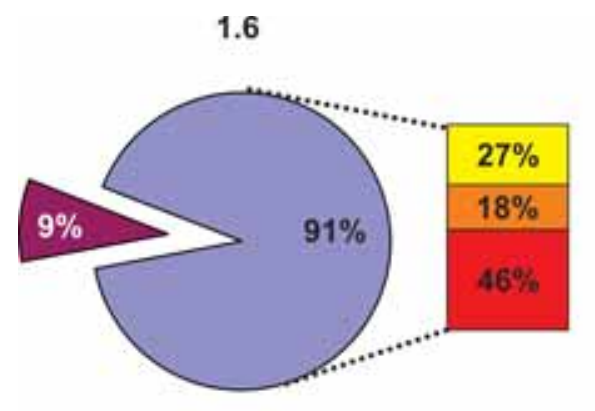

3.6

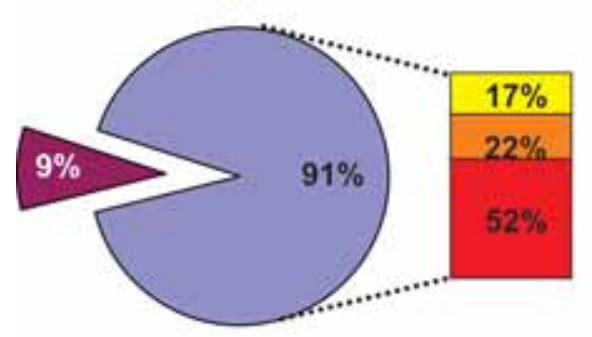

2.6

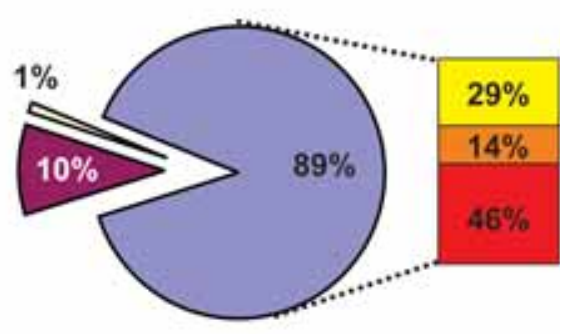

4.6

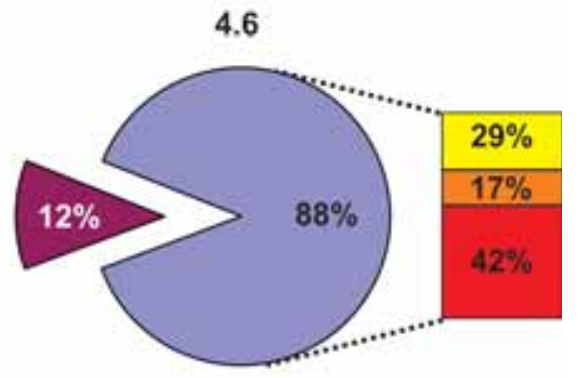

1/3 Mijlocie $\square$ Intregul dinte $\square$ vârf $\square$ Baza cuspidului a Intreagă 1/3 ocluzală

FIGURA 2. Topografia defectelor de hipomineralizare pe $M 1 p$ 


\section{e) Severitatea leziunilor tip MIH}

Raportat la severitatea leziunilor, s-a constatat că 26,8\% (n=98/366) dintre M1p cu MIH au avut defecte uşoare, $46,4 \%(n=170 / 366)$ defecte medii şi $26,8 \%(n=98 / 366)$ defecte severe.

La arcada inferioară, M1p cu defecte severe au fost statistic semnificativ mai frecvent întâlniţi decât la nivelul arcadei superioare, atât pe dreapta, cât şi pe stânga $(\mathrm{p}<0,05)$. Distribuţia în funcţie de severitate a fost relativ similară pentru fiecare molar (Fig. 3).

Incisivii au avut doar defecte uşoare (100\%).
1.6

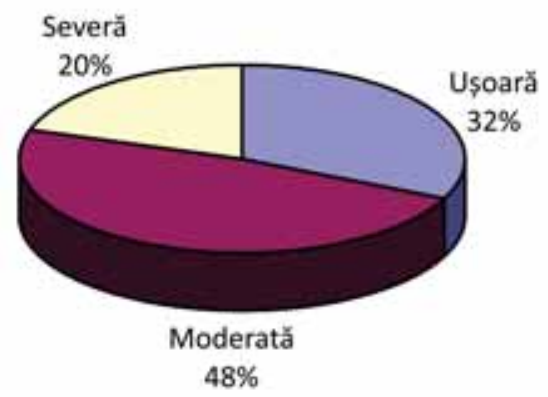

3.6

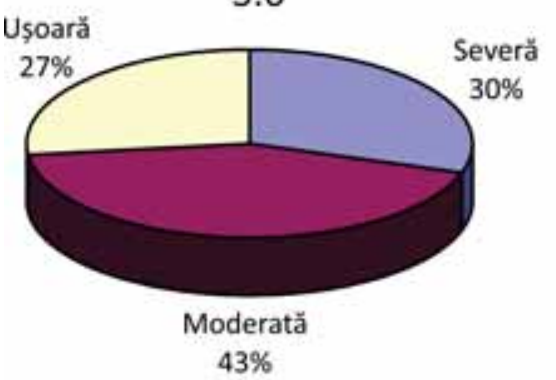

\section{f) Leziuni carioase asociate $\mathrm{MIH}$}

Dintre cei 100 de pacienţi cu MIH, 13\% nu au avut leziuni carioase asociate, $10 \%$ aveau $1 \mathrm{M} 1 \mathrm{p}$ cariat, $17 \%-2 \mathrm{M} 1 \mathrm{p}$ cu carii, $15 \%-3 \mathrm{M} 1 \mathrm{p}$ cariaţi şi $45 \%$ - toţi cei $4 \mathrm{M} 1 \mathrm{p}$ cu carii. Media pacienţilor cu MIH cu carii asociate a fost de 2,7.

Din cei 366 M1p cu MIH, 26,50\% (n=97/366) au fost indemni de carie, 52,18\% $(\mathrm{n}=191 / 366)$ au avut carii simple şi $21,31 \%(n=78 / 366)$ carii complicate. Distribuţia pe fiecare M1p în parte este prezentată în fig. 4.

FIGURA 3. Distribuția M1p în funcție de severitate
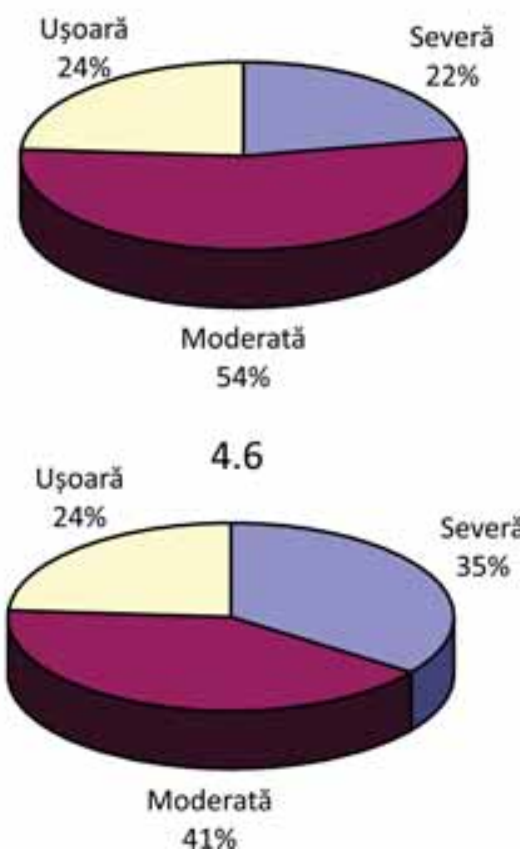

FIGURA 3. Distributila M1p in functie de severitate

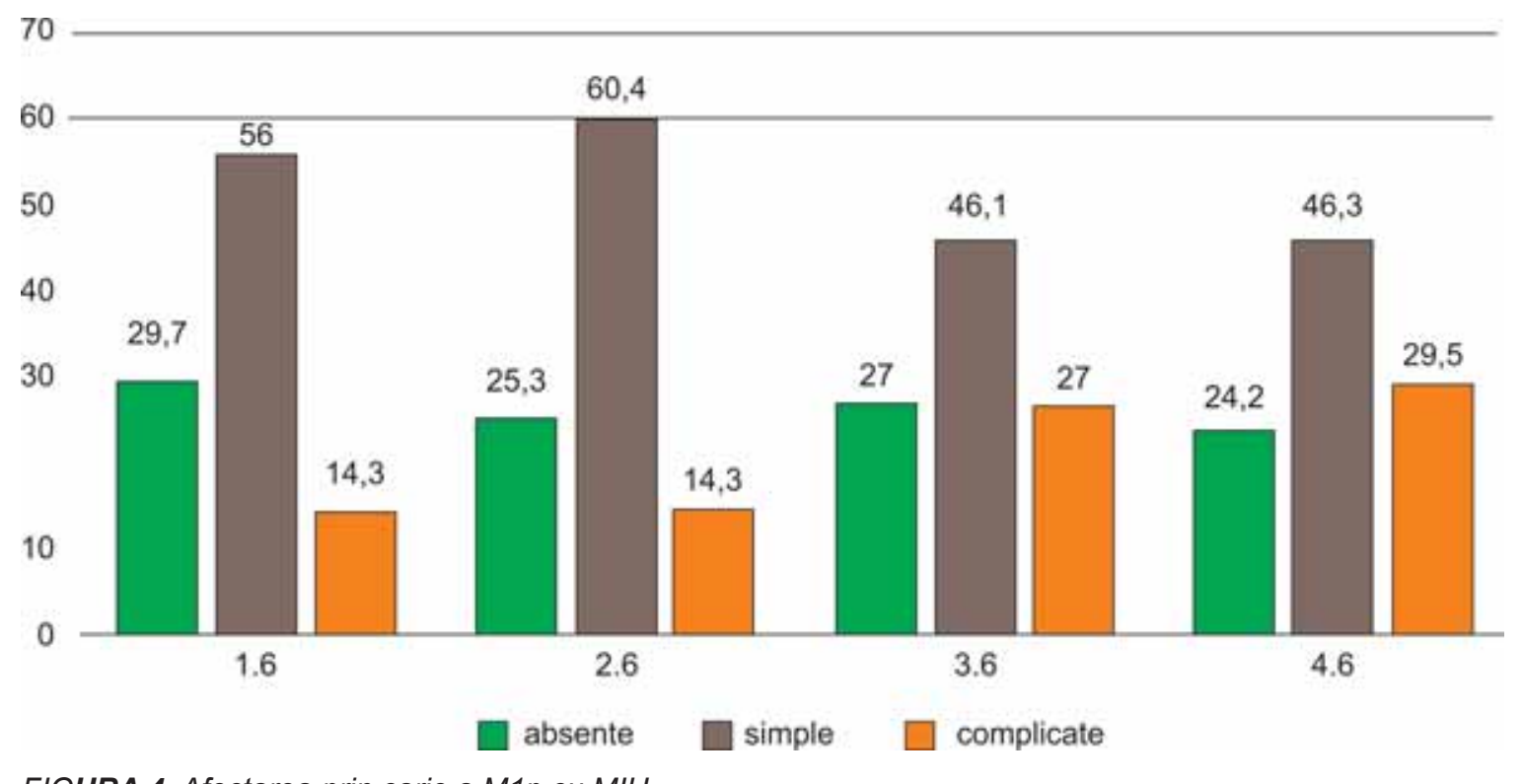




\section{DISCUŢII}

În studiul prezent, $52 \%$ dintre pacienţi au avut MIH şi 48\% MH. Garcia-Margarit şi col. (2014) (5) au găsit valori similare: $56,8 \%$ cu MIH şi $43,2 \%$ cu MH, în timp ce Koruyucu şi col. (2018) (6) au raportat valori diferite: $79,33 \% \mathrm{cu}$ MIH şi $20,67 \% \mathrm{cu}$ MH.

În cazul lotului studiat, MIH a fost semnificativ statistic mai frecvent la sexul feminin (62\%) decât la sexul masculin (38\%). Acest rezultat este în concordanţă cu majoritatea lucrărilor publicate, care au arătat că fetele sunt mai afectate de MIH decât băieţii (3, 6-10). Astfel, Lygidakis şi col. (2008) au arătat că 58,6\% dintre copiii cu MIH au fost fete şi $41,4 \%$ băieţi (7). Rezultate similare au obţinut şi Hernandez şi col. (2018): 9,41\% la fete faţă de 6,39\% la băieţi (8) şi Koruyucu şi col. (2018) (6): $15 \%$ la fete şi 13,4\% la băieţi. În schimb, alte studii nu au găsit diferenţe semnificative între sexe. De exemplu, în studiul lui Leppäniemi şi col. (2001), prevalenţa MIH a fost de 17,2\% la băieţi şi 21,1\% la fete, iar în studiul realizat de Luca şi col. 49,1\% dintre copiii cu MIH au fost băieţi şi 50,9\% fete $(9,10)$.

Media M1p cu MIH/copil la lotul studiat a fost de 3,66. Garcia-Margarit şi col. (2014) au raportat o medie de 2,4 M1p cu MIH/copil la un lot de 840 de pacienţi de 8 ani din Valencia, Spania (5), Negre-Barber şi col. (2018) o medie de 2,7 M1p la un lot de 100 de copii cu MIH cu vârsta medie 9,16 ani (11), iar Lygidakis şi col. (2008) de 5,7 dinţi afectaţi la un lot de 3.518 copii cu vârste de 5,5-12 ani din Grecia (7).

Mai multe studii au arătat că MIH este mai frecvent la molarii superiori decât la cei inferiori. Astfel, în studiul realizat de Leppäniemi şi col. în 2001, leziunile au fost mai frecvente la maxilar $(11,8 \%)$ decât la mandibulă $(8,4 \%)(9)$. De asemenea, Rizk şi col. (2018) au găsit un raport M1p maxilari/M1p mandibulari de 1,86/1 la băieţi şi 1,68/1 la fete (12), iar Martinez-Gomez şi col.(2012) au raportat 57,7\% dintre leziuni la maxilar şi $42,4 \%$ la mandibulă (13). Sunt însă şi studii care au arătat că M1p mandibulari au fost mai frecvent afectaţi. De exemplu, Jälevik (2001) a raportat că 11,5\% dintre M1p mandibulari şi 10,8\% dintre cei maxilari aveau leziuni de hipomineralizare (14). De asemenea, studiul efectuat de Calderara şi col. (2005) a relevat un procent uşor mai mare de afectare a molarilor mandibulari (15). Cercetarea de faţă a arătat că M1p maxilari au fost afectaţi aproximativ precum cei mandibulari: $91 \%$, respectiv $92 \%(p>0,05)$.

Numeroase studii, inclusiv cel prezent, au arătat că nu există diferenţe semnificative între prezenţa leziunilor tip MIH pe partea dreaptă sau pe partea stângă $(10,17)$.

În ceea ce priveşte topografia MIH, la lotul studiat s-a observat că defectele de hipomineralizare au fost localizate preferenţial în $1 / 3$ ocluzală $(69,67 \%)$ şi numai 7,92\% în $1 / 3$ medie. De asemenea, Leppäniemi şi col., în 2001, au raportat că $71,8 \%$ dintre leziuni erau situate în $1 / 3$ ocluzală. Zonele hipomineralizate au fost situate la nivelul marginilor incizale şi cuspizilor şi/sau extinse peste jumătate din suprafeţele vestibulare şi orale, în timp ce $1 / 3$ cervicală nu a fost niciodată atinsă (9). De asemenea, Luca şi col. (2007) au găsit că hipomineralizările la nivelul M1p erau localizate pe vârful cuspizilor în 77,3\% dintre cazuri şi pe întreaga suprafaţă cuspidiană în 22,7\% dintre cazuri (10). Acest lucru confirmă faptul că defectul de mineralizare are loc în primii 2 ani de viaţă ai copilului, atunci când coroanele M1p şi ale incisivilor permanenţi sunt în curs de mineralizare.

Referitor la severitatea $\mathrm{MIH}$, studiile au arătat rezultate contradictorii. Astfel, Petrou şi col. (2011) au observat că $85,57 \%$ dintre dinţii cu MIH aveau defecte uşoare şi $30,92 \%$ defecte moderate/severe (16). De asemenea, Janković şi col. (2004) au găsit că forma uşoară de hipomineralizare a fost cea mai frecventă - la 52,4\% dintre dinţii cu MIH, urmată de forma moderată - la 22,2\% (17). Şi în studiile efectuate în Arabia Saudită, Rizk şi col. (2018) şi Allazam şi col. (2014) au raportat că forma uşoară a fost cea mai frecventă $(12,18)$. În schimb, Chawla şi col. (2008) au raportat că numai $16 \%$ dintre cei 429 de M1p afectaţi au prezentat defecte uşoare şi $84 \%$ - defecte moderate sau severe (19). În 2010, Abbasoglu şi col. au constatat că $43,2 \%$ dintre M1p aveau defecte uşoare şi $56,8 \%$ defecte moderate sau severe (20). În studiul prezent, numai $26,8 \%$ dintre M1p au avut o formă uşoară, $46,4 \%$ - o formă moderată şi $26,8 \%$ - o formă severă.

Leppamieni şi col. (2001) susţin că severitatea leziunilor creşte odată cu numărul de dinţi afectaţi (9), iar potrivit lui Jasulaityte (2007), copiii cu mai mult de trei dinţi afectaţi sunt de 3,5 ori mai suscep- 
tibili de a avea MIH sever cu pierderea smalţului post-eruptiv faţă de copiii cu unul până la doi dinţi afectaţi (21). Similar, în studiul prezent, $80 \%$ dintre pacienţi au avut 4 M1p cu MIH, 46,4\% având defecte severe.

Este important de observat prevalenţa cariilor la aceşti pacienţi, deoarece atitudinea terapeutică şi evoluţia în timp variază foarte mult de la un caz la altul. Studiul prezent a arătat o prevalenţă ridicată a cariilor pe M1p cu sindrom MIH, 87\% dintre pacienţi având cel puţin un M1p cariat şi $45 \%$ toţi cei 4 M1p cariaţi. Astfel, 72,5\% dintre M1p maxilari şi 74,5\% dintre M1p mandibulari cu MIH au fost cariaţi. Aceste rezultate sugerează că prezenţa MIH reprezintă un mediu mai favorabil pentru dezvoltarea cariilor. Rezultate similare au fost raportate şi în alte studii. Astfel, Tadikonda şi col. (2015) au arătat că subiecţii cu MIH au prezentat un număr mai mare de carii de 1,43 ori decât cei care nu aveau MIH (22). Într-un studiu de tip caz-control, Grossi şi col. (2017) au arătat că la copiii cu MIH riscul de a dezvolta carii în smalţ sau în smalţ şi dentină este de 30 de ori mai mare decât la cei fără MIH (23). Garcia-Margarit şi col. (2014) au găsit că indicii DMF-T/S au fost semnificativ statistic mai mari la copiii cu MIH faţă de cei fără MIH (5). Rezultatele studiului realizat de Leppäniemi şi col. (2001) au fost şi ele în concordanţă cu aceste date (9). În schimb, Heitmuller şi col. (Germania, 2013) nu au

\section{BIBLIOGRAFIE}

1. Kellerhoff N.-M., Lussi A. L'hypominéralisation des molaires-incisives. Rev Mens Suisse Odontostomato 2004; 114(3): 243-53.

2. Weerheijm K.L., Duggal M., Mejare I. et al. Judgement criteria for Molar-Incisor Hypomineralisation (MIH) in epidemiological studies: A summary of the European Meeting on MIH held in Athens, 2003. Eur J Paediatr Dent 2003; 4(3): 110-3.

3. Mathu-Muju K., Wright J.T. Diagnosis and treatment of molar-incisor hypomineralisation. Comped Contin Educ Dent 2006; 27(11): 604-10.

4. Pentapati K.C., Yeturu S.K., Siddiq H. Systematic review and meta-analysis of the prevalence of molar-incisor hypomineralisation. J Int Oral 2017; 9(6): 243-50.

5. Garcia-Margarit M., Catala-Pizzaro M., Montiel-Company J.M. et al. Epidemiological study of molar-incisor hypomineralization in 8-year-old Spanish children. Int J Paediatr Dent 2014; 24(1): 14-22.

6. Koruyucu M., Ozel S., Tuna E.B. Prevalence and etiology of molar-incisor hypomineralisation (MIH) in the city of Istanbul. J Dent Sci 2018:1-11.

7. Lygidakis N.A., Dimou G., Marinou D. Molar-IncisorHypomineralisation (MIH) A retrospective clinical study in găsit o asociere între carii şi MIH, posibil din cauza riscului foarte scăzut la carie în populaţia studiată (24).

Prin frecvenţa destul de mare a defectelor severe şi a leziunilor carioase complicate grefate la acest nivel, studiul subliniază necesitatea controalelor stomatologice cât mai aproape de erupţia M1p pe arcadă, care să permită diagnosticarea precoce şi intervenţia prin metode cât mai puţin invazive.

\section{CONCLUZII}

Media M1p afectaţi/pacient a fost de 3,66. 80\% dintre pacienţi au avut hipomineralizări pe toţi cei patru M1p.

La 73,2\% dintre M1p afectaţi s-au observat defecte moderate/severe.

$87 \%$ dintre pacienţi au prezentat cel puţin o leziune carioasă pe M1p cu MIH, 45\% având toţi cei patru M1p cariaţi. Media M1p cu MIH cu leziuni carioase asociate a fost de 2,7.

Este necesară depistarea precoce a leziunilor MIH pentru a se putea preveni apariţia complicaţiilor.

Notă: Autorii au contribuit în mod egal la prezentul articol, de aceea toți sunt considerați autori principali.

Conflict of interest: none declared Financial support: none declared

Greek children. Possible medical aetiological factors. Eur Arch Paediatr Dent 2008; 9(4): 207-17.

8. Hernandez M., Boj J.R., Espasa E. et al. First permanent molars and permanent incisors teeth by tooth prevalence of Molar-Incisor Hypomineralisation in a group of Spanish schoolchildren. Acta Stomatol Croat 2018, 52 (1): 4-11.

9. Leppäniemi A., Lukinmaa P.L., Alaluusua S. Nonfluoride hypomineralizations in the permanent first molars and their impact on the treatment need. Caries Res 2001; 35(1): 36-40.

10. Luca R., Prelipcean D., Farcaşiu T. et al. Studiu epidemiologic privind patologia odontală la un lot de copii de 6-7 ani. Medicina Dentară Pediatrică 2007: 90-3.

11. Negre-Barber A., Montiel-Company J.M., Catala-Pizzaro M. et al. Degree of severity of molar-incisor hypomineralisation and its relation to dental caries. Sci Rep 2018; 8: 1248.

12. Rizk H., Al-Mutairi M.M., Habibullah M.A. The prevalence of molar-incisor hypomineralisation in primary schoolchildren aged 7-9 years in Qassim Region of Saudi Arabia. J Interdiscip Dentistry 2018; 8: 44-8.

13. Martinez-Gomez T.P., Guinot Jimeno F., Bellet Dalmau L.J. et al. Prevalence of molar-incisor hypomineralisation observed using transillumination in a group of children from Barcelona (Spain). Int J Paediatr Dent 2012; 22(2): 100-9. 
14. Jälevik B. Enamel hypomineralization in permanent first molars. A clinical, histo- morphological and biochemical study. Swed Dent J Suppl 2001; (149): 1-86.

15. Calderara P.C., Gerthoux P.M., Mocarelli P. et al. The prevalence of Molar Incisor Hypomineralisation (MIH) in a group of Italian school children. Eur J Paediatr Dent 2005; 6(2): 79-83.

16. Petrou M.A., Basner R., Splieth C.H. Prevalence of molar-incisor hypomineralisation (MIH) among German schoolchildren. Int J Paediatr Dent 2011; 21(1): 16.

17. Jankovic S., Ivanovic M., Davidovic B. et al. Distribution and characteristics of molar-incisor hypomineralization. Vojnosanit Pregl 2014;71: 730-4.

18. Allazzam S.M., Alaki S.M., EL Meligy O.A.S. Molar-incisor hypomineralisation, Prevalence and Etiology. Int J Dent 2014; $1: 8$.

19. Chawla N., Messer L.B., Silva M. Clinical studies on molar-incisor hypomineralisation. Part 1: Distribution and putative association. Eur Archs Paediatr Dent 2008; 9(4): 180-90.
20. Abbasoglu Z., Bakkal M., Bekiroglu N. et al. MIH: Prevalence and putative association. Eur Archs Paediatr Dent 2010: 62.

21. Jasulailyte L., Veerkamp J.S., Weerheijm K.L. Molar incisor hypomineralization: review and prevalence data from the study of primary school children in Kaunas/Lithuania. Eur Arch Paediatr Dent 2007; 8(2): 87-94.

22. Tadikonda A., Acharya S., Pentapati K.C. Prevalence of Molar Incisor Hypomineralization and its Relation with Dental Caries in School Children of Udupi District. World J Dent 2015; 6(3): 143-6.

23. Grossi J.A., Cabral R.N., Leal S.C. Caries experience in children with and without molar-incisor hypomineralisation: a case-control study. Caries Res 2017; 51(4): 419-24.

24. Heitmuller D., Thiering E., Hoffmann U. Is there a positive relationship between molar incisor hypomineralisations and the presence of dental caries? Int J Paediatr Dent 2013; 23(2): 116-24. 